\title{
ALMOST BS-COMPACT OPERATORS AND DOMINATION PROBLEM
}

\author{
Mohamed Hajji ${ }^{1}$ \\ ${ }^{1}$ Affiliation not available
}

January 20, 2021

Hosted file

BS-compact operator.pdf available at https://authorea.com/users/390644/articles/504918almost-bs-compact-operators-and-domination-problem 